\title{
Colonization of Pythium oligandrum in the Tomato Rhizosphere for Biological Control of Bacterial Wilt Disease Analyzed by Real-Time PCR and Confocal Laser-Scanning Microscopy
}

\author{
Shigehito Takenaka, Hiroyuki Sekiguchi, Kazuhiro Nakaho, Motoaki Tojo, Akira Masunaka, and Hideki Takahashi
}

First, second, and fifth authors: National Agricultural Research Center for Hokkaido Region, Shinsei, Memuro-cho, Kasaigun, Hokkaido 082-0081, Japan; third author: National Agricultural Research Center, Tsukuba 305-8666, Japan; fourth author: University of Osaka Prefecture, Sakai 599-8531, Japan; and sixth author: Department of Life Science, Graduate School of Agricultural Science, Tohoku University, Sendai 981-8555, Japan.

Accepted for publication 12 September 2007.

\begin{abstract}
Takenaka, S., Sekiguchi, H., Nakaho, K., Tojo, M., Masunaka, A., and Takahashi, H. 2008. Colonization of Pythium oligandrum in the tomato rhizosphere for biological control of bacterial wilt disease analyzed by real-time PCR and confocal laser-scanning microscopy. Phytopathology 98:187-195.

It recently has been reported that the non-plant-pathogenic oomycete Pythium oligandrum suppresses bacterial wilt caused by Ralstonia solanacearum in tomato. As one approach to determine disease-suppressive mechanisms of action, we analyzed the colonization of $P$. oligandrum in rhizospheres of tomato using real-time polymerase chain reaction (PCR) and confocal laser-scanning microscopy. The real-time PCR specifically quantified $P$. oligandrum in the tomato rhizosphere that is reliable over a range of $0.1 \mathrm{pg}$ to $1 \mathrm{ng}$ of $P$. oligandrum DNA from $25 \mathrm{mg}$ dry weight of soil. Rhizosphere populations of $P$. oligandrum from to-

mato grown for 3 weeks in both unsterilized and sterilized field soils similarly increased with the initial application of at least $5 \times 10^{5}$ oospores per plant. Confocal microscopic observation also showed that hyphal development was frequent on the root surface and some hyphae penetrated into root epidermis. However, rhizosphere population dynamics after transplanting into sterilized soil showed that the $P$. oligandrum population decreased with time after transplanting, particularly at the root tips, indicating that this biocontrol fungus is rhizosphere competent but does not actively spread along roots. Protection over the long term from root-infecting pathogens does not seem to involve direct competition. However, sparse rhizosphere colonization of $P$. oligandrum reduced the bacterial wilt as well as more extensive colonization, which did not reduce the rhizosphere population of $R$. solanacearum. These results suggest that competition for infection sites and nutrients in rhizosphere is not the primary biocontrol mechanism of bacterial wilt by P. oligandrum.
\end{abstract}

The non-plant-pathogenic oomycete Pythium oligandrum Drechsler is a common soil fungus with worldwide distribution (38) that has received considerable attention as a potential biocontrol agent because of its ability to parasitize a wide range of fungal and oomycete plant pathogens $(4,5)$. It also has the advantages of producing cell wall hydrolytic enzymes and antibiotics $(4,20,28)$, competing for nutrients $(22)$, promoting plant growth $(2,17)$, and inducing plant resistance (3). Previous studies have shown that $P$. oligandrum is an effective biocontrol agent of damping-off and root diseases caused by several soilborne plant fungal pathogens $(2,7,22,24)$. Recent investigations have focused on the forms of induced resistance exerted by this fungus. Biochemical analyses have provided evidence of the activation of phenylpropanoid and terpenoid pathways during the early events of tomato root colonization by P. oligandrum (16), and light and electron microscope studies have shown that the occurrence of limited and local host reactions in response to P. oligandrum colonization of tomato, such as the plugging of invaded cells with heterogeneous osmiophilic or electron-dense materials, probably were related to the enhancement of host resistance $(16,29)$. Ethylene levels in $P$. oligandrum oospore-treated tomato roots were transiently elevated 11 -fold from 6 to $8 \mathrm{~h}$ after treatment, followed by high expression of three ethylene-inducible defenserelated genes (12). Picard et al. (27) isolated a soluble elicitor

Corresponding author: S. Takenaka; E-mail address: stake@affrc.go.jp

doi:10.1094/PHYTO-98-2-0187

(C) 2008 The American Phytopathological Society protein, oligandrin, from culture filtrates, and our group purified two elicitor proteins, POD-1 and POD-2, from cell wall fractions of $P$. oligandrum $(35,36)$.

It is likely that $P$. oligandrum must colonize the rhizosphere before it can trigger a defense response and it also is likely that this colonization causes $P$. oligandrum to compete directly with pathogens and other nonpathogenic rhizosphere organisms for space and nutrients. Many studies have shown a relationship between increased colonization of the rhizosphere by a nonpathogen and disease suppression (43). Martin and Hancock (22) showed that $P$. oligandrum actively colonized the endosperms and emerging radicles of sugar beet seedlings, but was a poor colonizer of secondary roots when seed were treated with oospores. McQuilken et al. (24) also reported that P. oligandrum did not appear to be rhizosphere competent on cress and sugar beet. On the contrary, Al-Rawahi and Hancock (1) found that P. oligandrum colonized the rhizosphere of 11 crop species grown in $P$. oligandrum-infested sterilized potting mix or an unsterilized mineral soil, even though the density of colonization in the former was higher than the latter. Le Floch et al. (18) reported that P. oligandrum was a strong colonizer of the tomato rhizosphere in hydroponic systems. These findings raise some doubt about whether $P$. oligandrum really has the ability to aggressively colonize the rhizosphere in field soils to act as an effective biocontrol agent. This is an important consideration because the complex interactions that take place in the rhizosphere between biocontrol agents and indigenous microbiota need to be considered during development of commercial microbial products (43). Thus, further studies detailing rhizosphere colonization by 
P. oligandrum are required, and can be much aided with the application of modern monitoring techniques such as real-time polymerase chain reaction (PCR) and confocal laser-scanning microscopy.

Previous studies $(1,18)$ have used direct isolation of $P$. oligandrum by selective media to quantify populations on roots or in soils (i.e., CFU or percent root colonization), but these methods are time consuming and may not have sufficient sensitivity or specificity to give an accurate count or location of fungal propagules or somatic structures. Real-time PCR recently has been used to determine the levels of soilborne plant pathogen DNA in infected plant tissue and soil and in microbe interactions with high reproducibility and sensitivity $(6,9,13,15)$. Real-time PCR provides a means of detecting and quantifying specific target DNA by monitoring PCR product accumulation, measured as increased fluorescence during cycling. There are three main strategies to generate the fluorescence signals. The first uses sequence-independent dyes that fluoresce when intercalated with doublestranded DNA (e.g., SYBR green I; Molecular Probe Inc., Eugene, OR, USA), and the second uses a single probe that enzymatically releases fluors (e.g., TaqMan; Roche Molecular Systems Inc., Alameda, CA, USA). The third uses two adjacent hybridization probes in which the fluorescence is generated by resonance energy transfer from a donor fluor on one probe to an acceptor fluor on the other (e.g., hybridization probes; Roche Applied Science, Mannheim, Germany). In this study, we developed a quantification method for P. oligandrum in the rhizosphere of tomato plants using a hybridization probe assay based on the high specificity of detection found in a comparative study of the methods (26). Furthermore, we examined an immuno-enzymatic staining procedure with confocal laser-scanning microscopy to visualize $P$. oligandrum on the roots of tomato. Using these complementary methods, we determined the ability of this fungus to colonize the tomato rhizosphere. Recently, our group found that $P$. oligandrum was able to suppress bacterial wilt caused by Ralstonia solanacearum in tomato (12). This soilborne bacterium colonizes on the root surface, infects roots through root tips and lateral root cracks, and rapidly develops within intercellular spaces of the inner cortex. Subsequently, it progresses toward xylem vessels and, finally, causes wilting of the tomato plants (39). Determination of the colony population density of $P$. oligandrum in the tomato rhizosphere and the level of bacterial wilt over the course of disease suppression would serve as a useful tool for the evaluation of one of the suspected primary mechanisms of P. oligandrum biocontrol.

\section{MATERIALS AND METHODS}

Fungal cultures. Five isolates of $P$. oligandrum, nine other Pythium spp., and four non-oomycete fungal species were used to test specificity (Table 1). Our previous study (36) divides $P$. oligandrum isolates into two groups based on the number of major proteins in their cell wall protein fractions (CWPs). Isolates with two major proteins (D-type) and isolates with one major protein (S-type) were used. Genomic DNA from isolates with either two major proteins (D-type) or one major protein (S-type) was tested for PCR cross-amplification. Pythium isolates were grown in liquid B medium amended with penicillin at $100 \mu \mathrm{g} / \mathrm{ml}(23)$ or in V8 broth $\left(100 \mathrm{ml}\right.$ of Campbell's V8 juice, $1.5 \mathrm{~g}$ of $\mathrm{CaCO}_{3}$ per litter) at $25^{\circ} \mathrm{C}$ for 3 to 14 days. Aphanomyces cochlioides, Fusarium oxysporum, Rhizoctonia solani, and Sclerotinia sclerotiorum were grown in Difco potato dextrose broth at 20 or $25^{\circ} \mathrm{C}$ for 3 to 15 days. Mycelial mats were collected by filtration, washed with distilled water, and blotted dry with a paper towel for the extraction of genomic DNA.

For the production of large quantities of $P$. oligandrum oospores, $P$. oligandrum isolate MMR10 was grown in containing $0.1 \%$ wheat germ oil at $25^{\circ} \mathrm{C}$ for 28 days. At harvest, mycelia were washed with sterile distilled water several times, and then transferred aseptically to a Waring blender cup. After homogenization at $14,000 \mathrm{rpm}$ for $5 \mathrm{~min}$ to disrupt hyphae without causing any obvious physical damage to the oospores, oospore concentration was adjusted to $1 \times 10^{6}$ oospores $/ \mathrm{ml}$ with sterile distilled water and stored at $4^{\circ} \mathrm{C}$. Although this suspension mainly consisted of oospores, it was considered to be a mycelial homogenate because it contained some hyphal debris.

TABLE 1. Fungal isolates tested with hybridization probe assay ${ }^{\mathrm{u}}$

\begin{tabular}{|c|c|c|c|c|c|}
\hline Species name & Isolate number & Habitat & Origin & $\begin{array}{c}\text { GenBank } \\
\text { accession no. }\end{array}$ & $\mathrm{C}_{\mathrm{T}}$ \\
\hline \multicolumn{6}{|l|}{ Pythium oligandrum } \\
\hline D-type & $\mathrm{MMR}^{\mathrm{v}}$ & Soybean soil & Hokkaido & AB302881 & $23.34 \pm 0.40$ \\
\hline D-type & MMR10v & Wheat soil & Hokkaido & AB302884 & $23.08 \pm 0.23$ \\
\hline D-type & MAFF240291w & Vegetable soil & Oosaka & AB355600 & $22.27 \pm 0.10$ \\
\hline S-type & $\mathrm{MMR}^{\mathrm{v}}$ & Wheat soil & Hokkaido & AB302882 & $22.41 \pm 0.27$ \\
\hline S-type & MMR8v $^{v}$ & Wheat soil & Hokkaido & AB302883 & $23.67 \pm 0.34$ \\
\hline \multicolumn{6}{|l|}{ Other Pythium spp. } \\
\hline$P$. acanthicum & MAFF240293w & Spinach soil & Saga & AB302889 & $42.97 \pm 1.76$ \\
\hline P. acanthophoron & $A-1-2-4^{x}$ & Wheat & Hokkaido & AB355644 & $45.00 \pm 0.00$ \\
\hline P. vanterpoolii & NBRC31923y & Barley & Fukui & $\ldots$ & $39.85 \pm 1.79$ \\
\hline P. volutum & NBRC31927y & Barley & Fukui & $\ldots$ & $45.00 \pm 0.00$ \\
\hline P. torulosum & NBRC32168y & Maschrengrass & Kagawa & $\ldots$ & $41.89 \pm 1.80$ \\
\hline P. irregulare & NBRC32072y & Tulip & Kyoto & $\ldots$ & $45.00 \pm 0.00$ \\
\hline P. ultimum & Py71-1 & Sugar beet soil & Hokkaido & AB355596 & $40.89 \pm 2.38$ \\
\hline P. deliense & MAFF240292w & Vegetable soil & Osaka & $\ldots$ & $45.00 \pm 0.00$ \\
\hline P. aphanidermatum & MAFF240290w & Vegetable soil & Osaka & $\ldots$ & $41.02 \pm 2.31$ \\
\hline \multicolumn{6}{|l|}{ Other fungal species } \\
\hline Aphanomyces cochlioides & MMRA $1^{\mathrm{v}}$ & Sugar beet & Hokkaido & $\ldots$ & $43.52 \pm 1.48$ \\
\hline Fusarium oxysporum f. sp. radicis-lycopersici & MAFF103047w & Tomato & Koch & $\ldots$ & $43.70 \pm 1.30$ \\
\hline Rhizoctonia solani AG2-2 & Pf $-28^{v}$ & Sugar beet & Hokkaido & $\ldots$ & $45.00 \pm 0.00$ \\
\hline Sclerotinia sclerotiorum & $\mathrm{Sm} 5 \mathrm{f}-1^{\mathrm{z}}$ & Kidney bean & Hokkaido & $\ldots$ & $45.00 \pm 0.00$ \\
\hline
\end{tabular}

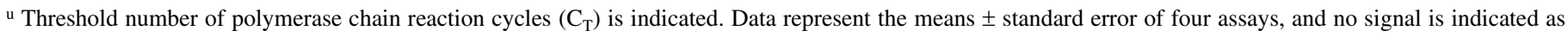
$\mathrm{C}_{\mathrm{T}}=45.00$.

$\checkmark$ Maintained in our laboratory.

${ }^{w}$ Provided by National Institute of Agrobiological Sciences, Japan.

x Provided by N. Kondo, Hokkaido University, Japan.

y Provided by National Institute of Technology and Evaluation, Japan.

z Provided by I. Saito, Hokkaido University, Japan. 
Plant material. Laboratory-grown miniature tomato cv. MicroTom, which is valuable as a functional genomic tool for plant pathology $(31,33)$, was seeded in unsterilized or sterilized Brown Andosol, which is a well-drained, fine volcanic ash soil, in plastic trays $(28$ by $54.5 \mathrm{~cm}$ ) divided into 128 cones ( 3 by 3 by $5 \mathrm{~cm}$ ). The sterilized soil was kept in an autoclave bag (Fisher Scientific, Pittsburgh, PA, USA) at room temperature for $\approx 1$ month after being autoclaved at $121^{\circ} \mathrm{C}$ for $2 \mathrm{~h}$ until use. Plants were grown for 3 weeks in a growth chamber at 25 and $20^{\circ} \mathrm{C}$ (day and night) with a $16-\mathrm{h}$ photoperiod $\left(66.5 \mathrm{~W} / \mathrm{m}^{2}\right)$. Each plant was fertilized with $5 \mathrm{ml}$ of a 500-fold-diluted Hyponex solution (Hyponex Japan, Osaka, Japan) at 1 week intervals.

Rhizosphere colonization of $\boldsymbol{P}$. oligandrum. To evaluate the efficiency of rhizosphere colonization of $P$. oligandrum, each soil cone was watered with $5 \mathrm{ml}$ of mycelial homogenate containing different oospore concentrations $\left(0,5 \times 10^{2}, 5 \times 10^{3}, 5 \times 10^{4}, 5 \times\right.$ $10^{5}$, or $5 \times 10^{6}$ ) just before seeding. Three weeks after growth under the above conditions, four to six plants from each treatment were used for determination of $P$. oligandrum rhizosphere populations with real-time PCR in both unsterilized and sterilized soil conditions and confocal laser-scanning microscopic observation in only unsterilized soil condition. Plants were uprooted gently from each cone to preserve the small feeder roots and were shaken to remove clumps of soil around roots. For the determination of rhizosphere populations, these plants additionally were shaken in a plastic bag to collect as many soil particles adhering to root surfaces as possible. To observe root surfaces, whole roots then were fixed in FAA solution (formalin, acetic acid, 95\% ethanol, and water, 135:45:450:315) (42) for microscopic observation. Soil dry weights were determined after incubation at $70^{\circ} \mathrm{C}$ for $48 \mathrm{~h}$, and these data were used to calculate the concentration of $P$. oligandrum DNA per gram dry weight of rhizosphere soil.

Dynamics of $P$. oligandrum in the rhizosphere after transplanting. To assess changes of $P$. oligandrum populations in the rhizosphere after transplanting into $P$. oligandrum-free soil, seedlings were prepared by sowing seed into sterilized soil cones containing different oospore concentrations $\left(5 \times 10^{4}, 5 \times 10^{5}\right.$, or $5 \times 10^{6}$ ). Four weeks after growth under the above conditions, each seedling was transplanted into sterilized field soil in a plastic pot $(9 \mathrm{~cm}$ in diameter by $9 \mathrm{~cm}$ deep). Rhizosphere soils from two to three plants of each treatment were collected as above $0,2,4$, and 6 weeks after transplanting. The root systems from harvested plants were divided into root bases and root tips. The experiment was repeated three times.

Inoculation of Ralstonia solanacearum. To evaluate the relationship between the efficiency of rhizosphere colonization of $P$. oligandrum and the level of bacterial wilt disease suppression, seedlings grown in sterilized soil cones containing different oospore concentrations $\left(0,5 \times 10^{2}, 5 \times 10^{3}, 5 \times 10^{4}, 5 \times 10^{5}\right.$, or $5 \times 10^{6}$ ) for 3 weeks under the above conditions were inoculated with Ralstonia solanacearum strain 8242 (race 1, biovar 4). The bacterial suspension was adjusted to $1 \times 10^{7} \mathrm{CFU} / \mathrm{ml}$ as described previously (25). Roots of the P. oligandrum-inoculated tomato plants were injured by directly piercing each soil cone in four places $\approx 1 \mathrm{~cm}$ part from a base of hypocotyl with a skewer and watered with $5 \mathrm{ml}$ of the bacterial suspension. Inoculated plants were incubated in a growth chamber at $30^{\circ} \mathrm{C}$ with a 16 -h photoperiod. Six plants in each treatment were used to assay disease severity, and the experiment was repeated five times. Disease severity was measured 10 days after inoculation and categorized on a 0 -to- 4 scale, where $0=$ no wilting, $1=1$ to $25 \%$ wilting, $2=$ 26 to $50 \%$ wilting, $3=51$ to $75 \%$ wilting, and $4=76$ to $100 \%$ wilting or dead (30). To determine whether rhizosphere colonization of $R$. solanacearum is affected by the precolonization of $P$. oligandrum, rhizosphere soils were collected 4 days after inoculation as described above, and rhizosphere populations of $R$. solanacearum were determined by plating diluted soil onto selective medium (11). Two plants from each treatment were used for determination of $R$. solanacearum rhizosphere population, and the experiment was repeated three times. The effect of preinoculation with $P$. oligandrum oospores on suppression of bacterial wilt disease and bacterial rhizosphere population was determined by an analysis of variance (ANOVA) with a randomized block design. Dunnett's one-sided $t$ test was used to determine significant differences in disease severity between mycelial homogenates and distilled water treatments $(P<0.05)$. Bacterial counts were transformed using $\log _{10}$ before performing the ANOVA, and a comparison of bacterial rhizosphere population between treatments was done by Tukey's studentized range test $(P<0.05)$.

DNA extraction. Fungal genomic DNA was extracted from 50 to $100 \mathrm{mg}$ (wet weight) of ground fungal cultures using the DNeasy plant DNA extraction kit as described by the manufacturer (Qiagen Inc., Mississauga, ON, Canada). DNA was eluted in $100 \mu \mathrm{l}$ of buffer and quantified by measuring its absorbance at $260 \mathrm{~nm}$. Total soil DNA was extracted from 0.2 to $0.3 \mathrm{~g}$ of soil (expressed as dry weight) using a Bio 101 FastDNA SPIN kit as described by the manufacturer (Qbiogene, Inc., Irvine, CA) with some modifications. To increase DNA extraction efficiency from soil, a fecal dry bead tube containing quartz (MoBio Laboratories, Inc., Solana Beach, CA) was used instead of the original FastDNA SPIN kit tube, and $100 \mu \mathrm{l}$ of a $20 \%$ skim milk solution was added to the tube along with $978 \mu$ l of sodium phosphate buffer and $122 \mu \mathrm{l}$ of MT buffer to avoid degradation and adsorption of DNA to soil particles (40). The tube was processed three times in a FastPrep apparatus (Thermo Savant, Holbrook, $\mathrm{NY}$ ) at speed level 6.5 for $45 \mathrm{~s}$ with 5-min cooling periods between each process. After elution from the SPIN Filter with DES (Qbiogene, Inc.), the DNA solution was mixed with an equal volume of chloroform, vortexed thoroughly, and centrifuged for $5 \mathrm{~min}$ at $14,000 \times g$. The DNA was precipitated with $100 \%$ ethanol and washed with $80 \%$ ethanol. The purified DNA was redissolved in $56 \mu$ l of sterile Milli Q water and quantified as above.

PCR primers and hybridization probes. A species-specific primer set and two adjacent fluorescent-labeled hybridization probes for fluorescence resonance energy transfer were used to amplify $P$. oligandrum DNA. The $P$. oligandrum-specific primers P.OLG.F1 and P.OLIG.R04 designed by Godfrey et al. (10) were used to produce a 384-bp amplicon within the internal transcribed spacer (ITS) region of ribosomal (r)DNA. The PCR product was cloned into pGEM-T Easy Vector (Promega Corp., Madison, WI) and transformed into Escherichia coli JM109 (Promega Corp.). Plasmid DNA was purified with a GFX Micro Plasmid Prep Kit (Amersham Biosciences, Piscataway, NJ), and sequencing was performed on an ABI 3130 Genetic Analyzer (Applied Biosystems Inc., Foster City, CA) using a BigDye Terminator Cycle Sequencing FS Ready Reaction Kit (Applied Biosystems Inc.) according to the manufacturer's instructions.

To design two $P$. oligandrum-specific adjacent fluorescentlabeled hybridization probes, HybriOLI-1 and HybriOLI-2, multiple alignment of the ITS region from 25 Pythium spp. $(P$. oligandrum, accession number AB302881; $P$. aphanidermatum, AY598622; P. deliense, AY598674; P. myriotylum, AY598678; P. torulosum, AY598624; P. graminicola, AY598625; P. arrhenomanes, AY598628; P. vanterpoolii, AY598685; P. volutum, AY598686; P. dissotocum, AY598634; P. insidiosum, AY598637; P. acanthicum, AF330196; P. rostratum, AY598696; P. pleroticum, AY598642; P. spinosum, AY598701; P. irregulare, AY598702; P. sylvaticum, AY598645; P. iwayamai, AY598648; P. paddicum, AY598707; P. helicandrum, AY598653; P. ultimum var. ultimum, AY598657; P. acanthophoron, AY598711; and P. vexans, AY598713) was conducted using CLUSTAL-X (37). These species were selected as representative of each of 11 phylogenetic clades from A to K based on the rDNA ITS region (19). The $3^{\prime}$ end of HybriOLI-1 and the 5' end of HybriOLI-2 were labeled with Fluorescein and Red640, respectively. Primers and 
probes used in this study were synthesized by Hokkaido System Science (Hokkaido, Japan) and Nihon Gene Research Laboratory (Miyagi, Japan), respectively.

Real-time quantitative PCR assay. Real-time PCR amplifications were carried out in glass capillaries (Roche Diagnostics, Tokyo) in a total volume of $20 \mu \mathrm{l}$ using a LightCycler (Roche
Diagnostics). The reaction mixture consisted of $2 \mu \mathrm{l}$ of LightCycler FastStart DNA Master HybProbe (Roche Diagnostics), $4 \mathrm{mM} \mathrm{MgCl}_{2}, 300 \mathrm{nM}$ each primer, $200 \mathrm{nM}$ HybriOLI-1 probe, and $400 \mathrm{nM}$ HybriOLI-2 probe. Extracted fungal DNA was diluted to $100 \mathrm{pg} / \mu \mathrm{l}$ and $1 \mu \mathrm{l}$ of each sample was used in the $20-\mu \mathrm{l}$ real-time PCR mixtures. Reactions containing sterile Milli Q

A
P. oligandrum
P. acanthicum
P. aphanidermatum
P. deliense
P. arrhenomanes
P. graminicola
P. myriotylum
P. torulosum
P. vanterpoolii
P. volutum
P. dissotocum
P. insidiosum
P. rostratum
P. pleroticum
P. irregulare
P. spinosum
P. sylvaticum
P. iwayamai
P. paddicum
P. helicandrum
P. ultimum
P. acanthophoron
P. vexans

B

P. oligandrum

P. acanthicum

P. oligandrum

P. acanthicum

P. oligandrum

P. acanthicum

P. oligandrum

P. acanthicum

P. oligandrum

P. acanthicum

P. oligandrum

P. acanthicum

P. oligandrum

P. acanthicum
HybriOLI-1

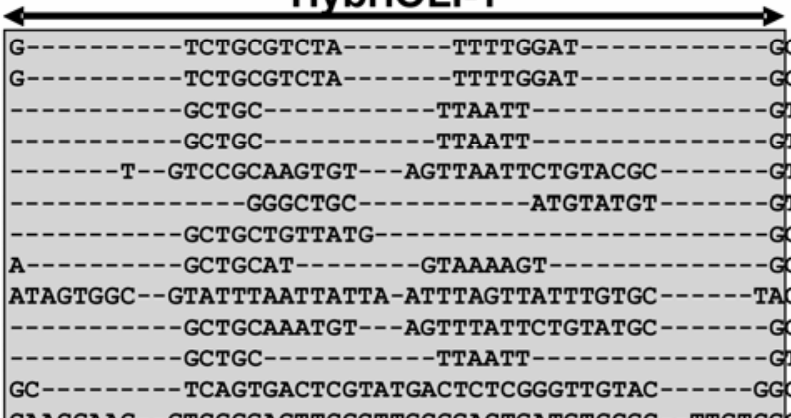

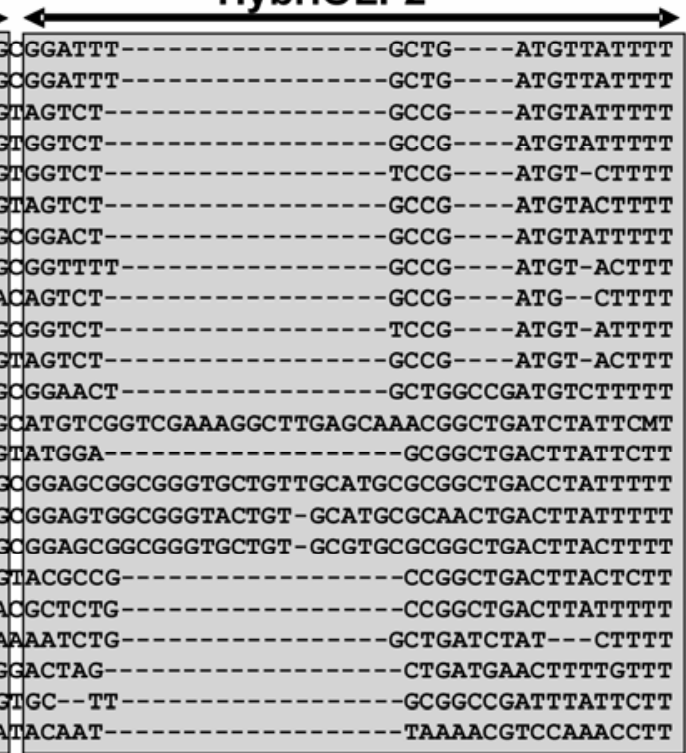

P.OLIG.F1

1 CTGTGCTTCGTC-----GCAAGACTTGAGGTGAACGAAGGTGAGTCTGCGTCTATTTT 54

1 CTGTGCTTCGTCTTCATCGTAAGATTTGAGGCTGAACGAAGGTGAGTCTGCGTCTATTTT 60

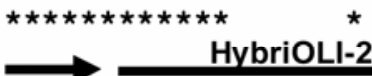

55 GGATGCGGATTTCTGATGTTATTTTAAACACCTATTACTTAATACTGAACTATACTCCG 114

61 GGATGCGGATTTGCTGATGTTATTTTAAACACCTATTACTTAATACTGAACTATACTCCG 120

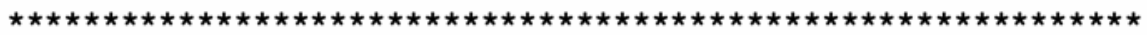

5.8S rRNA

115 AATACGAAAGTTTTGGTTTTAACAATTAA CAACTTTCAGCAGTGGATGTCTAGGCTCGC 174

121 AATACGAAAGTTTTGGTTTTAACAATTAACAACTTTCAGCAGTGGATGTCTAGGCTCGC 180

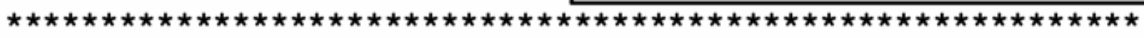

175 ACATCGATGAAGAACGCTGCGAACTGCGATACGTAATGCGAATTGCAGAATTCAGTGAGT 234

181 ACATCGATGAAGAACGCTGCGAACTGCGATACGTAATGCGAATTGCAGAATTCAGTGAGT 240

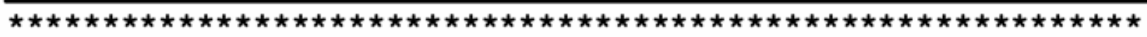

235 CATCGAAATTTTAACGCATATTGCACTTTCGGGTTATGCCTGGAAGTATGCCTGTATCA 294

241 CATCGAAATTTTGAACGCATATTGCACTTTCGGGTTATGCCTGGAAGTATGCCTGTATCA 300

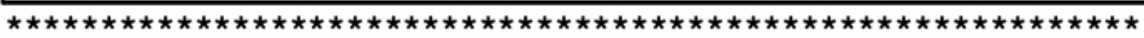

295 GTGTCCGTA CATCAAACTTGCCTTTCTTTTTTTTGTAGTCAAAATTAGAGATGGCAGAA 354

301 GTGTCCGTA CATCAAACTTGTCTTTCTTTTTTTGTGTAGTCAAAATTAGAGATGGCAGAA 360

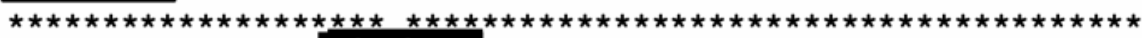
P.OLIG.R04

355 TGTGAGGTGTCTCGCGCTGTCTTTTT---AAAG

384

361 TGTGAGGTGTCTCGCGCTGTCTTTTTTAAAAAG

393

Fig. 1. Comparison of internal transcribed spacer (ITS) region sequences of Pythium oligandrum and other Pythium spp. A, ClustalX multiple alignment of nucleotide sequence from HybriOLI-1 and HybriOLI-2 designed from ITS region 1 of P. oligandrum with corresponding regions of 22 selected Pythium spp. B, ClustalX multiple alignment of ITS region sequences of $P$. oligandrum (accession number AY598618) and P. acanthicum (AF330196). P.OLIG.F1 and P.OLIG.R04 are specific primers designed by Goodfrey et al. (10). Gaps introduced for alignment are indicated by hyphens. 
water without genomic DNA served as negative controls for each PCR. The thermal cycling conditions for PCR were as follows: after initial denaturation at $95^{\circ} \mathrm{C}$ for $10 \mathrm{~min}$, samples were amplified for 45 cycles by touchdown PCR (8) with denaturation at $95^{\circ} \mathrm{C}$ for $10 \mathrm{~s}$, annealing on a decline ramp of $1^{\circ} \mathrm{C}$ from 70 to $55^{\circ} \mathrm{C}$ every second cycle over the first 16 cycles and then at $55^{\circ} \mathrm{C}$ for the last 29 cycles for $20 \mathrm{~s}$, and primer extension at $72^{\circ} \mathrm{C}$ for $15 \mathrm{~s}$. Fluorescence was monitored during the annealing step at $640 \mathrm{~nm}$. Fluorescence intensity is correlated with the number of accumulated PCR amplicons. The PCR cycle at which the increase in fluorescence of a sample exceeded the background noise of 0.04 was defined as the threshold cycle $\left(\mathrm{C}_{\mathrm{T}}\right)$.

Quantification of $P$. oligandrum DNA in soil samples. Soil DNA sample concentrations were adjusted to correspond to the DNA amount extracted from $25 \mathrm{mg}$ of soil expressed as dry weight. To test whether PCR inhibitors were present in soil DNA samples, two standard curves were made by diluting extracted P. oligandrum DNA from $100 \mathrm{pg} / \mu \mathrm{l}$ to $1 \mathrm{fg} / \mu \mathrm{l}$ with sterile Milli Q water or soil DNA solution extracted from $25 \mathrm{mg}$ of sterilized soil, and comparing their reactivity in real-time PCR. A standard curve was generated by the Fit Points analysis method in the LightCycler Data Analysis software (version 3.5; Roche Diagnostics), with the fit point number set at 2 . Using this method, the $\log$ of the concentration of the P. oligandrum DNA dilution series was plotted versus the $\mathrm{C}_{\mathrm{T}}$ value. The concentrations of $P$. oligandrum DNA in soil samples then could be calculated by comparing $\mathrm{C}_{\mathrm{T}}$ values to the crossing-point values of the linear regression line of the standard curve. Real-time PCR was conducted at least three times for each sample.

Confocal laser-scanning microscopy analysis. Whole roots of tomato plants from the $P$. oligandrum colonization test were immunocytochemically stained. Root tissues fixed with FAA as described above were washed briefly with TBST (20 mM Tris$\mathrm{HCl}, 0.15 \mathrm{M} \mathrm{NaCl}, 0.05 \% \mathrm{NaN}_{3}, 0.05 \%$ Tween $20, \mathrm{pH} 7.5$ ) and incubated for $45 \mathrm{~min}$ in TBST containing $3.0 \%$ bovine serum albumin (BSA) to block nonspecific antibody binding sites. The blocked root tissues then were incubated for $1 \mathrm{~h}$ with antiserum against the deglycosylated $32-\mathrm{kDa}$ protein of $P$. iwayamai (34), which recognizes Pythium cell wall proteins, at a 1:500 dilution with TBST containing $0.2 \%$ BSA. After washing three times for 5 min per wash with excess TBST, the tissues were incubated with the Alexa Fluor $488 \mathrm{~F}\left(\mathrm{ab}^{\prime}\right)_{2}$ fragment of goat anti-rabbit immunoglobulin G, (Invitrogen Life Technologies, Carlsbad, CA) for $1 \mathrm{~h}$ at a 1:500 dilution with TBST containing 0.2\% BSA. After washing three times for $5 \mathrm{~min}$ per wash with excess TBST, stained samples were placed on glass slides in drops of $2.5 \%$ of DABCO (Sigma-Aldrich, St. Louis) in Mowiol (Calbiochem, La

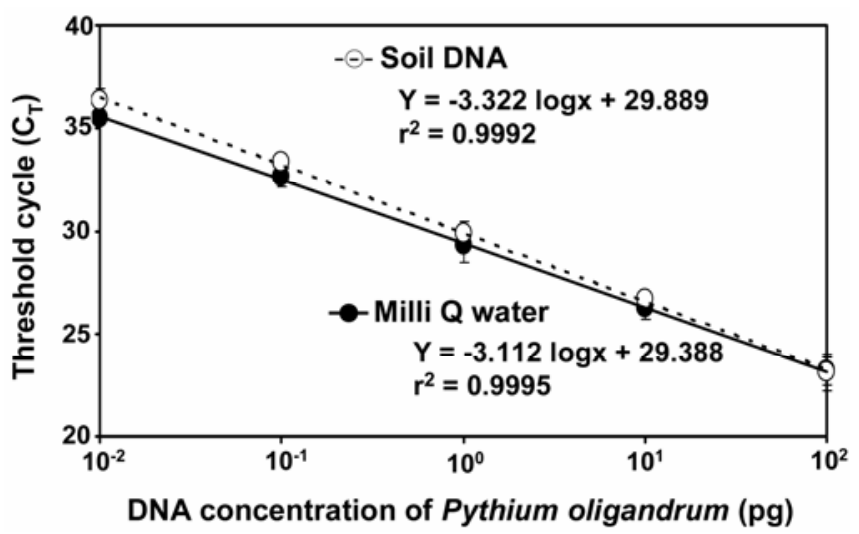

Fig. 2. Standard curves of Pythium oligandrum DNA in a real-time polymerase chain reaction hybridization probe assay. The threshold cycle $\left(C_{T}\right)$ values are plotted against the concentration of diluted DNA with Milli $Q$ water or soil DNA solution (log scale). Error bars represent standard deviation of the means of three independent experiments.
Jolla, CA) as an anti-fading mounting medium, and covered with a coverslip. Microscopy analysis was performed with a FluoView FV1000 confocal laser scanning unit (Olympus, Tokyo) with an argon ion laser attached to an Olympus BX61 microscope equipped with UplanSApo $20 \times / 0.75,40 \times / 0.90$, and $60 \times / 1.20 \mathrm{w}$ objectives (Olympus). The excitation source was an argon ion laser for Alexa Fluor 488 visualization (excitation dichroic mirror DM405/488, barrier filter BA505 IF). Z-stacks were collected with Z-steps of $1.24,0.62$, and $0.31 \mu \mathrm{m}$ for $20 \times / 0.75,40 \times / 0.90$, and $60 \times / 1.20 \mathrm{w}$ objectives, respectively.

\section{RESULTS}

Specificity of real-time PCR analysis. A real-time PCR hybridization probe assay using ITS rDNA oligonucleotides was developed for detection and quantification of $P$. oligandrum. The ITS rDNA nucleotide sequences amplified with $P$. oligandrumspecific primers P.OLIG.F1and P.OLIG.R04 designed by Godfrey (10), 384-bp amplicons, were compared among five $P$. oligandrum isolates (MMR2, -3, -8, and -10 and MAFF240291) in this study and one New Zealand isolate (NZWM07) in the GenBank database. There was only a two-nucleotide difference among MMR2 (accession number AB302881), MMR3 (AB302882), MMR8 (AB302883), MMR10 (AB302884), MAFF240291 (AB355600), and NZWM07 (AF364536), showing that the selected ITS region is highly conserved within this species. The $P$. oligandrum-specific hybridization probes HybriOLI-1 and HybriOLI-2, which are separated by one base, were designed from an ITS-1 region exhibiting variability from another 24 Pythium spp., except for $P$. acanthicum (Fig. 1A). Although $P$. acanthicum and $P$. oligandrum have very similar ITS sequences because both species belong to the same phylogenetic clade based on ITS region of rDNA (19), their annealing sites for the primers P.OLIG.F1 and P.OLIG.R04 have different sequences (Fig. 1B). The DNA from five isolates of $P$. oligandrum, nine Pythium spp., and four non-Pythium fungal species was checked for cross reactivity of primers and probes (Table 1). The five P. oligandrum isolates, including D- and S-types, had strong fluorescence signals and similar $\mathrm{C}_{\mathrm{T}}$ values. On the other hand, very weak or no signals were obtained from the other nine Pythium spp., including $P$. acanthicum isolate MAFF240293, or from A. cochlioides, $F$. oxysporum f. sp. radicis-lycopersici, $R$. solani AG2-2, and $S$. sclerotiorum (Table 1). These results indicate that, at least for the fungal isolates tested, the real-time PCR assay is specific to P. oligandrum.

Quantification of $\boldsymbol{P}$. oligandrum in soil. Genomic DNA of P. oligandrum isolate MMR10 was serially diluted from $100 \mathrm{pg} / \mu \mathrm{l}$

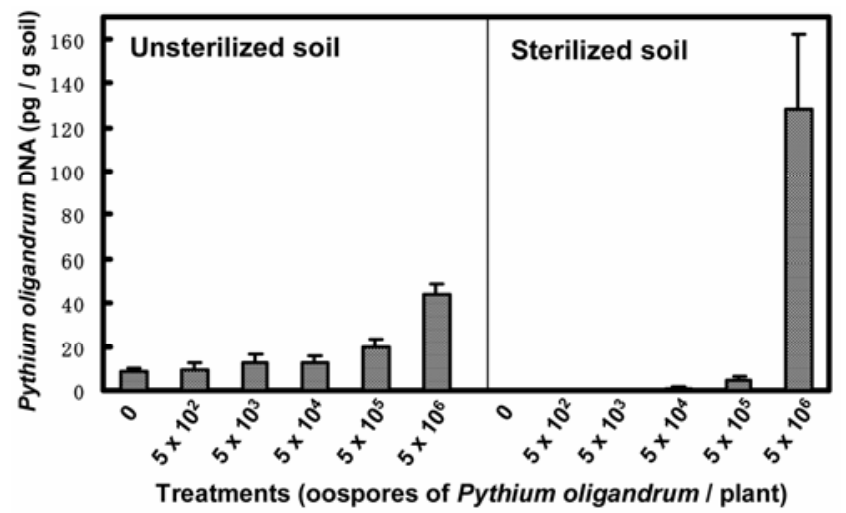

Fig. 3. Rhizosphere soil populations of Pythium oligandrum of tomato plants grown for 3 weeks in unsterilized or sterilized field soils initially treated with different concentrations of oospores. The P. oligandrum population was expressed as the DNA concentration determined by real-time polymerase chain reaction hybridization probe assay. Error bars represent standard error of the means of three independent experiments. 
to $1 \mathrm{fg} / \mu \mathrm{l}$ with sterile Milli Q water or DNA solution isolated from $25 \mathrm{mg}$ dry weight (dw) of sterilized soil to test the sensitivity of the real-time PCR assay. There was a strong linear $\left(R^{2}=0.999\right)$ inverse relationship between $\mathrm{C}_{\mathrm{T}}$ and $\log _{10}$ ( $P$. oligandrum DNA concentration) over five orders of magnitude from $100 \mathrm{pg}$ to 10 fg, with little variation between triplicate samples in either dilution series (Fig. 2). Two calibration curves were compared to test for the potential presence of PCR inhibitors in soil DNA samples. There was no significant difference $(P<0.05)$ in the slopes and intercepts for dilution series with Milli Q water and soil DNA solution, indicating that there were no detectable soil PCR inhibitors to interfere with the quantification of $P$. oligandrum in soil.

Rhizosphere population of $\boldsymbol{P}$. oligandrum in tomato. The amount of $P$. oligandrum genomic DNA in the rhizosphere of tomato grown for 3 weeks in unsterilized or sterilized field soils with initial applications of different concentrations of oospores was determined by real-time PCR hybridization probe assay (Fig. $3)$. No amplification product was obtained from sterilized soil without the addition of oospores, whereas $9.0 \mathrm{pg}$ of $P$. oligandrum DNA/g of dry soil were detected from unsterilized soil without the addition of oospores, indicating that indigenous $P$. oligandrum, or at least its DNA, was in the field soil used in this study. Soil assayed with differential medium (21) contained viable $P$. oligandrum (data not shown). Although there was some native $P$. oligandrum in unsterilized soil, populations of $P$. oligandrum in the tomato rhizosphere increased with the application of at least $5 \times 10^{5}$ oospores per plant. A similar trend was observed in sterilized soil, but the amounts of $P$. oligandrum DNA detected from the rhizosphere of tomato plants grown in $5 \times 10^{6}$ oospores/ plant treatment in sterilized soils always were higher than in unsterilized soil.

Tomato root surface colonization by $\boldsymbol{P}$. oligandrum. Confocal laser-scanning microscopic observation with immunocytochemical staining provided a tool for visualization of $P$. oligandrum on tomato roots after 3 weeks of plant growth in sterilized soils with initial applications of oospores $\left(5 \times 10^{4}, 5 \times 10^{5}\right.$, or $\left.5 \times 10^{6}\right)$. Hyphal development was observed more frequently on the root surface than oogonium development. $P$. oligandrum colonized the tomato root by attaching to root hairs (Fig. 4A) and by growing along the surface of the root (Fig. 4B). Some fungal biomass colonized tightly on the root surface and could not be removed by
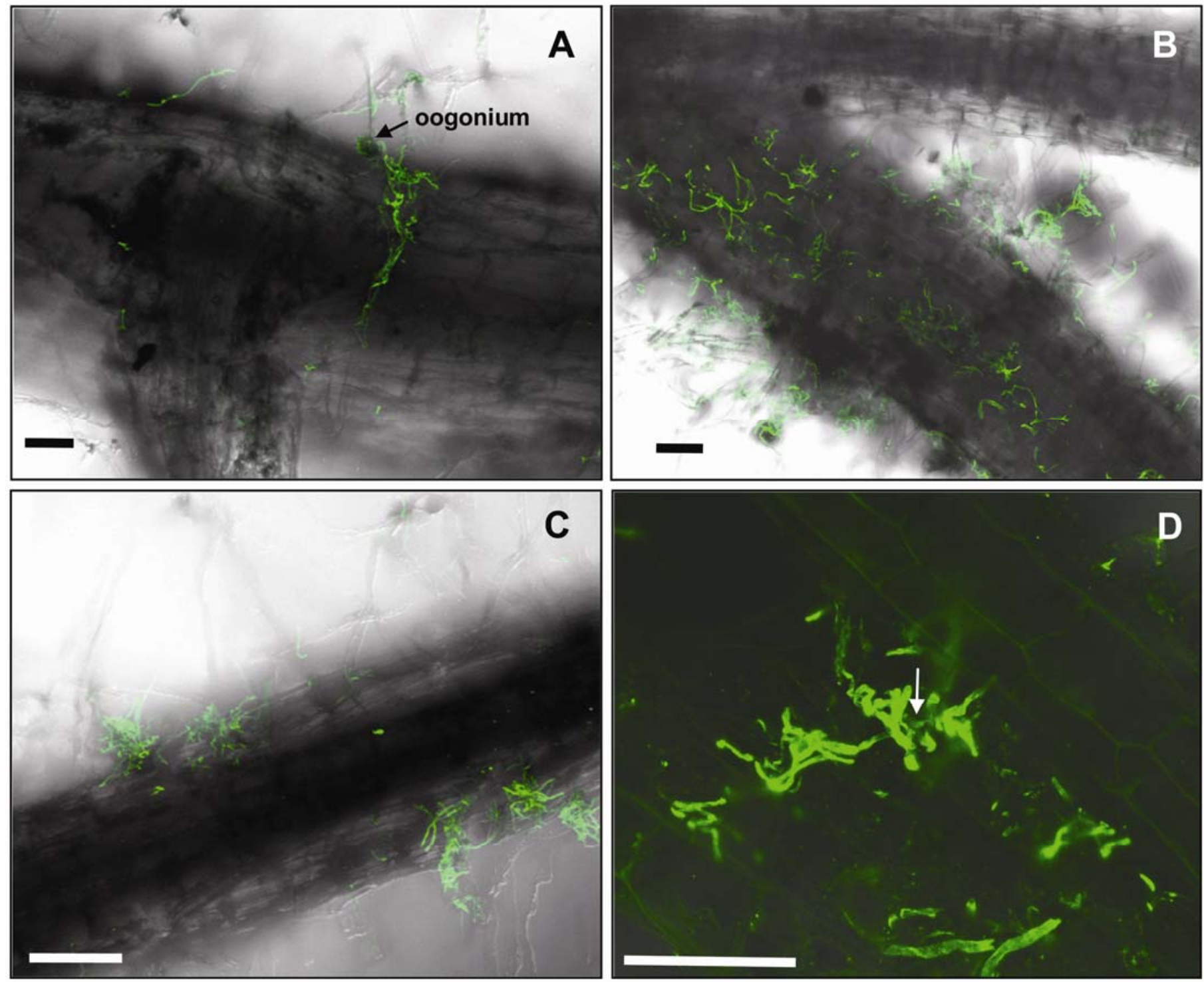

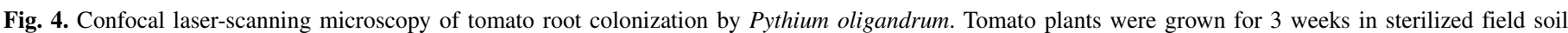

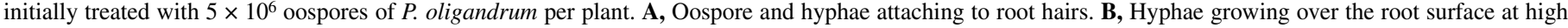

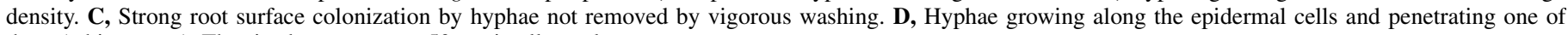
them (white arrow). The size bar represents $50 \mu \mathrm{m}$ in all panels. 
vigorously washing with tap of water (Fig. 4C). Hyphal penetration into root epidermal cells was observed at these tightly adherent colonization sites (Fig. 4D). Additionally, tomato root colonization was quantified by determining colonization frequency as the percentage of visual fields with $P$. oligandrum colonization (Table 2). Colonization frequency in the $5 \times 10^{5}$ and $5 \times 10^{6}$ oospore treatments was significantly higher than treatment with $5 \times 10^{4}$ oospores. Root colonization was most frequently and abundantly observed in tomato seedlings grown in sterilized soil treated with $5 \times 10^{6}$ oospores.

Rhizosphere population dynamics of $P$. oligandrum after transplanting. The changes of $P$. oligandrum population in the rhizosphere of plants grown for 4 weeks in sterilized soil initially treated with $5 \times 10^{4}, 5 \times 10^{5}$, or $5 \times 10^{6}$ oospores, followed by transplanting into sterilized soil, were determined by real-time PCR hybridization probe assay (Fig. 5). Rhizosphere populations decreased with time after transplanting, but the rate of decrease was different between the root base and the root tip. At the root tip, the population sharply declined to a minimum level by 2 weeks after transplanting (6 weeks after seeding), whereas a gradual population decrease occurred by 6 weeks after transplanting (10 weeks after seeding) at the root base. The amount of $P$. oligandrum DNA 6 weeks after transplanting (10 weeks after seeding) was $1.8 \mathrm{pg} / \mathrm{g}$ of dry rhizosphere soil at the root tips from plants initially treated with $5 \times 10^{6}$ oospores, but the amounts were below the detection limit for real-time PCR in the $5 \times 10^{4}$ and $5 \times 10^{5}$ oospore treatments.

Bacterial wilt suppression. To determine the minimum inoculum concentration of $P$. oligandrum required for suppression of bacterial wilt disease, tomato seedlings were grown for 3 weeks in sterilized soils initially treated with $5 \times 10^{2}$ to $5 \times 10^{6} /$ plant.

TABLE 2. Root colonization frequency of Pythium oligandrum in tomato plants initially treated with different concentrations of its oospores after 3 weeks of growth ${ }^{y}$

\begin{tabular}{lc}
\hline Treatment & Colonization frequency $(\%)^{\mathrm{z}}$ \\
\hline $5 \times 10^{4}$ oospores/plant & $14.8 \pm 5.2 \mathrm{a}$ \\
$5 \times 10^{5}$ oospores/plant & $52.4 \pm 10.3 \mathrm{~b}$ \\
$5 \times 10^{6}$ oospores/plant & $76.2 \pm 2.9 \mathrm{~b}$ \\
\hline
\end{tabular}

y Colonization was determined as the percentage of visual fields in which $P$. oligandrum was detectable, with 44 to 50 fields per experiment in three replicates, by confocal laser-scanning microscopy.

z Values are the means \pm standard error of three replicates and values followed by a different letter within columns are significantly different using Tukey's studentized range test $(P<0.05)$ after angular transformation of percentage data.
Plants then were challenged with $5 \times 10^{7} \mathrm{CFU} /$ plant of Ralstonia solanacearum. Ten days after inoculation with $R$. solanacearum, disease severity was compared with plants grown in soil without the addition of oospores. At an inoculum concentration of $>5 \times$ $10^{4}$ oospores/plant, $P$. oligandrum significantly reduced disease severity compared with the control (Table 3). Although there was an inverse correlation between bacterial wilt disease severity and $P$. oligandrum inoculum concentration, there was no significant difference among the $5 \times 10^{4}, 5 \times 10^{5}$, and $5 \times 10^{6}$ oospores/plant treatments according to a least significant difference test $(P<$ $0.05)$, indicating that an inoculum concentration of $5 \times 10^{4}$ oospores/plant was sufficient to give maximum protection from bacterial wilt disease. Additionally, $R$. solanacearum rhizosphere populations 4 days after inoculation were compared. Inoculum concentrations of $>5 \times 10^{4}$ oospores/plant reduced pathogen populations slightly but not significantly compared with the control (Table 4). Furthermore, there was no significant difference in pathogen populations in the rhizosphere among the $5 \times 10^{4}, 5 \times$ $10^{5}$, and $5 \times 10^{6}$ oospores/plant treatments, although the rhizosphere populations of $P$. oligandrum was quite different among them (Fig. 3, sterilized soil).

\section{DISCUSSION}

In this study, we developed a real-time PCR hybridization probe assay for the quantification of $P$. oligandrum in soil and, using this method, examined the colonization of this fungus in the tomato rhizosphere. The primary advantages of the use of hybridization probes in real-time PCR is that the binding of two additional probes results in increased specificity compared with

TABLE 3. Disease severities caused by Ralstonia solanacearum in tomato initially treated with different concentrations of oospores of Pythium oligandrum ${ }^{\mathrm{y}}$

\begin{tabular}{lc}
\hline Treatment & Disease severity ${ }^{z}$ \\
\hline Control $(0$ oospore/plant $)$ & $3.40 \pm 0.25$ \\
$5 \times 10^{2}$ oospores/plant & $3.07 \pm 0.25$ \\
$5 \times 10^{3}$ oospores/plant & $2.68 \pm 0.41$ \\
$5 \times 10^{4}$ oospores/plant & $2.45 \pm 0.40^{*}$ \\
$5 \times 10^{5}$ oospores/plant & $2.27 \pm 0.35^{*}$ \\
$5 \times 10^{6}$ oospores/plant & $2.27 \pm 0.40^{*}$ \\
\hline
\end{tabular}

y Values are the means \pm standard error of five independent experiments and asterisks indicate significant difference $(P<0.05)$ compared with control according to Dunnett's test.

${ }^{\mathrm{z}}$ Disease severity was estimated on a 0 -to- 4 scale, where $0=$ no wilting, $1=1$ to $25 \%$ wilting, $2=26$ to $50 \%$ wilting, $3=51$ to $75 \%$ wilting, and $4=76$ to $100 \%$ wilting or dead.
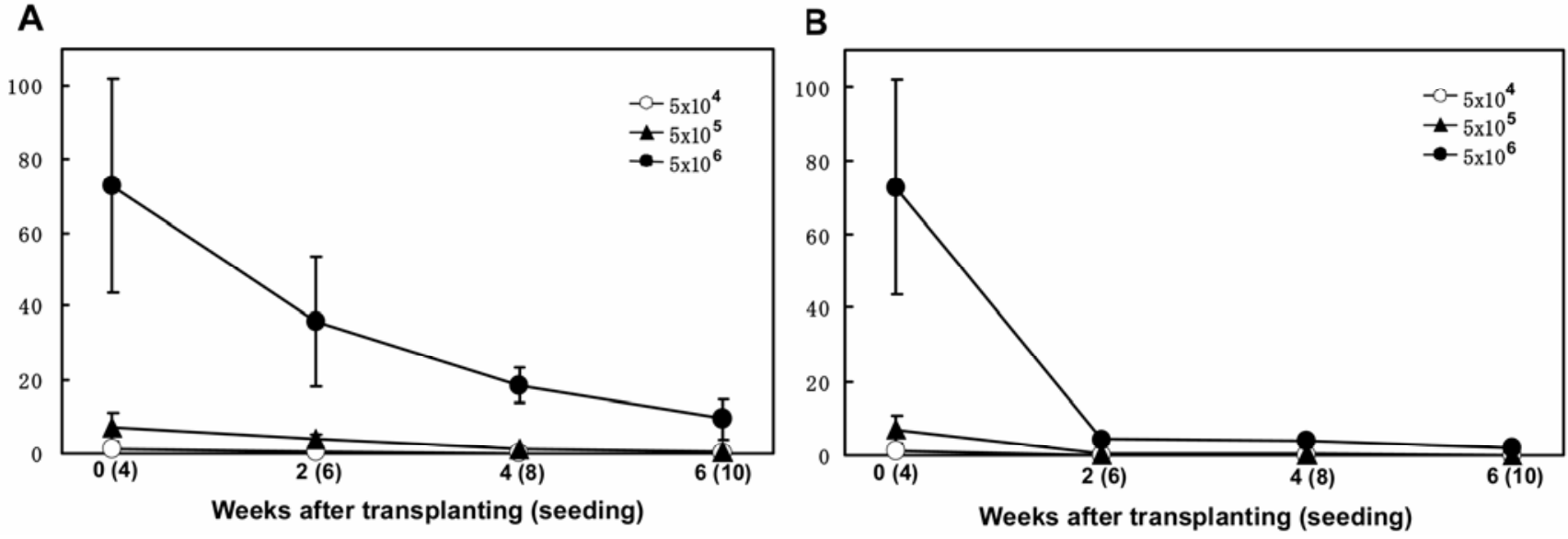

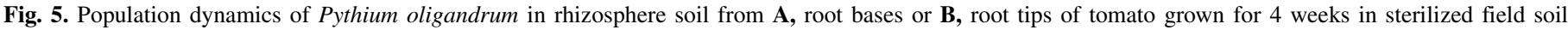

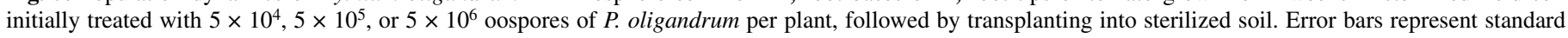
error of the means of three independent experiments. 
other real-time PCR assays such as SYBR Green I and TaqMan (26). We used P. oligandrum-specific primers (10) and hybridization probes (Fig. 1A) designed from the ITS region because ITS- 1 and -2 are ideal for the production of specific primers that have potential for differentiating Pythium species $(19,41)$. The primer and probe sets of $P$. oligandrum used in this assay were checked against the corresponding nucleotide sequences of other representative Pythium spp. belonging to each of 11 phylogenetic clades from $\mathrm{A}$ to $\mathrm{K}$, into which Lévesque and de Cock divided 116 species and varieties of Pythium based on the ITS region of rDNA. $P$. acanthicum has an ITS sequence very similar to its fellow clade species $P$. oligandrum (19) and has identical HybriOLI-1 and HybriOLI-2 probe hybridization sites (Fig. 1B), but different annealing sites for the primers P.OLIG.F1 and P.OLIG.R04. Thus, the combination of the primers and probes was found to be specific for $P$. oligandrum within the context of the isolates tested in this work. This was borne out by the experimental results, which indicated detection and quantification with high fidelity to $P$. oligandrum among the nine Pythium spp., including a $P$. acanthicum isolate, and four non-Pythium fungal species. There was no difference in reactivity by any of the Dtype or S-type $P$. oligandrum isolates (Table 1). The reaction conditions of the primer and probe sets have been optimized such that they provide an almost linear response and can quantify the DNA concentration of this fungus from $0.1 \mathrm{pg}$ to $1 \mathrm{ng}$ from $25 \mathrm{mg}$ $\mathrm{dw}$ of soil. These results suggest that real-time PCR with the above primer and probe sets can be used to quantify the biomass of $P$. oligandrum with highly specificity from soil.

We examined $P$. oligandrum colonization of the tomato rhizosphere using the complementary approaches of nucleotide quantification by real-time PCR and direct observation by confocal laser-scanning microscopy. Complex interactions can take place in the rhizosphere between biocontrol agents and indigenous microbes (43). Although $P$. oligandrum populations from the rhizospheres of tomato grown in the $5 \times 10^{6}$ oospores/plant treatment was lower in unsterilized soil than in sterilized soil, its rhizosphere population increased with the application of at least $5 \times 10^{5}$ oospores/plant (Fig. 3), suggesting that $P$. oligandrum is rhizosphere competent for space (i.e., root zone niches or attachment) and nutrients with native soil microflora when its oospores are directly applied to soil. To confirm this trait in P. oligandrum, further studies currently are being undertaken by differentiating the introduced $P$. oligandrum isolate from indigenous isolates in native soils and by determining the rhizosphere populations of this fungus in tomato grown in other soil types under different microfloral regimes. Confocal microscopic observation also showed strong rhizosphere colonization by $P$. oligandrum, in which this fungus developed over the tomato root surface and some hyphae strongly colonized and penetrated into root epidermal cells (Fig. 4). The penetration into tomato root tissues by $P$. oligandrum had been observed with light and transmission electron microscopy of root tissue sections $(16,29)$. The frequency

TABLE 4. Rhizosphere soil populations of Ralstonia solanacearum of tomato plants initially treated with different concentrations of oospores of Pythium oligandrum at 4 days after inoculation ${ }^{y}$

\begin{tabular}{lc}
\hline Treatment with oospores & $R$. solanacearum at CFU $\times 10^{7} \mathrm{~g}^{-1 \mathrm{z}}$ \\
\hline Control $(0$ oospore/plant $)$ & $5.64 \pm 4.21 \mathrm{a}$ \\
$5 \times 10^{2}$ oospores/plant & $5.31 \pm 3.51 \mathrm{a}$ \\
$5 \times 10^{3}$ oospores/plant & $6.02 \pm 4.42 \mathrm{a}$ \\
$5 \times 10^{4}$ oospores/plant & $4.03 \pm 2.23 \mathrm{a}$ \\
$5 \times 10^{5}$ oospores/plant & $3.29 \pm 1.79 \mathrm{a}$ \\
$5 \times 10^{6}$ oospores/plant & $4.18 \pm 2.87 \mathrm{a}$ \\
\hline
\end{tabular}

y Tomato plants were grown for 3 weeks and the inoculum concentration of $R$. solanacearum was $5 \times 10^{7}$ cfu per plant.

$\mathrm{z}$ Values are the means \pm standard error of three independent experiments and values followed by a different letter within columns are significantly different using Tukey's studentized range test $(P<0.05)$. of $P$. oligandrum colonization observed on the roots obviously was higher when the initial application of oospore concentration was high (Table 2), which corresponds with the result obtained by real-time PCR assays. Martin and Hancock (21) and McQuilken et al. (24) reported that $P$. oligandrum was not rhizosphere competent on sugar beet and cress when their seed were coated with its oospores, which may be due to the differences in oospore treatments (seed coating versus direct soil application). We also determined changes in rhizosphere population after transplanting into sterilized soil, and found that $P$. oligandrum population decreased with time after transplanting, particularly at the root tips (Fig. 5). This result indicates that $P$. oligandrum does not appear to actively spread its population along roots and does not protect over the longer term from root-infecting pathogens with direct competition for infection sites and nutrients.

Larkin and Fravel (14) determined the primary mechanisms of action of three nonpathogenic Fusarium isolates (CS-1, CS-20, and Fo47) for the biocontrol of Fusarium wilt of tomato by varying the inoculum levels of the biocontrol agent and pathogen in soil and with subsequent mathematical modeling. Isolate CS20 controlled disease effectively with only 100 chlamydospores/g of soil (c/gs) with pathogen concentrations of up to $10^{5} \mathrm{c} / \mathrm{gs}$, suggesting that this control was largely due to induced resistance. In contrast, Fo47 was effective only at $10^{4}$ to $10^{5} \mathrm{c} / \mathrm{gs}$, regardless of pathogen density, suggesting that this isolate was active primarily through competition for nutrients (14). It is likely that increasing the propagule density of $P$. oligandrum in the rhizosphere protects plants from disease by increasing the competition for space and nutrients, thereby decreasing the activity of the pathogen. However, in the interactions between $P$. oligandrum and $R$. solanacearum in the tomato rhizosphere, increasing the inoculum concentration of $P$. oligandrum from $5 \times 10^{4}$ oospores/ plant to $5 \times 10^{6}$ oospores/plant did not further reduce disease severity (Table 3 ). The rhizosphere population of $P$. oligandrum of tomato initially treated with $5 \times 10^{6}$ oospores/plant was represented by $\approx 130 \mathrm{pg}$ of $P$. oligandrum DNA/g of dry soil, which is 25 and 130 times higher than those initially treated with $5 \times 10^{5}$ and $5 \times 10^{4}$ oospores/plant, respectively (sterilized soil in Fig. 3). Microscopic observations found that the colonization frequency of the $5 \times 10^{4}$ oospore treatment was only $15 \%$ (Table 2 ), which means that $85 \%$ of visual fields on tomato root surface were free of $P$. oligandrum. These $P$. oligandrum-free root areas included the elongation zones and the axils of emerging or developed secondary roots, where $R$. solanacearum preferably colonizes (39). Furthermore, reduction of the pathogen population in the rhizosphere was not significant in the $5 \times 10^{4}, 5 \times 10^{5}$, or $5 \times$ $10^{6}$ oospore treatments (Table 4 ). These results indicate that direct competition for infection sites and nutrients is unlikely to be main motive force in the reduction of bacterial wilt by $P$. oligandrum.

Phenolic precursors accumulate within $3 \mathrm{~h}$ of inoculation with $P$. oligandrum, followed by rishitin synthesis by $14 \mathrm{~h}$ after inoculation (16). Recently, our group found that ethylene- and jasmonic acid-dependent signaling pathways were significantly accelerated in tomato treated with a mycelial homogenate of $P$. oligandrum (12; S. Hase, K. Nakaho, T. Arie, S. Seo, Y. Ohashi, S. Takenaka, and H. Takahashi, unpublished data). Furthermore, macroarray analysis indicated that 144 genes, including defense-related genes such as pathogenesis-related protein P14 and class II chitinase genes, were upregulated in tomato roots treated with a cell wall protein fraction of $P$. oligandrum containing two elicitor proteins (32). These results suggest that the main mechanism by which P. oligandrum controls tomato bacterial wilt is induced resistance.

\section{ACKNOWLEDGMENTS}

This research was supported by a Research and Development Program for New Bio-industry Initiatives grant from the Bio-oriented Technology Research Advancement Institution, Japan. We thank N. Kondo (Hokkaido 
University) for providing a Pythium acanthophoron isolate, I. Saito (Hokkaido University) for providing a Sclerotinia sclerotiorum isolate, and T. Kono and M. Yamaguchi for their technical assistance.

\section{LITERATURE CITED}

1. Al-Rawahi, A. K., and Hancock, J. G. 1997. Rhizosphere competence of Pythium oligandrum. Phytopathology 87:951-959.

2. Al-Rawahi, A. K., and Hancock, J. G. 1998. Parasitism and biological control of Verticillium dahliae by Pythium oligandrum. Plant Dis. 82:1100-1106.

3. Benhamou, N., Rey, P., Cherif, M., Hockenhull, J., and Tirilly, Y. 1997. Treatment with the mycoparasite Pythium oligandrum triggers induction of defense-related reactions in tomato roots when challenged with Fusarium oxysporum f. sp. radicis-lycopersici. Phytopathology 87:108122.

4. Benhamou, N., Rey, P., Picard, K., and Tirilly, Y. 1999. Ultrastructural and cytochemical aspects of the interaction between the mycoparasite Pythium oligandrum and soilborne plant pathogens. Phytopathology 89:506-517.

5. Brožová, J. 2002. Exploitation of the mycoparasitic fungus Pythium oligandrum in plant protection. Plant Prot. Sci. 38:29-35.

6. Cullen, D. W., Lees, A. K., Toth, I. K., and Duncan, J. M. 2002. Detection of Colletotrichum coccodes from soil and potato tubers by conventional and quantitative and real-time PCR. Plant Pathol. 51:281-292.

7. Davanlou, M., Madsen, A. M. Madsen, C. H., and Hockenhull, J. 1999. Parasitism of macroconidia, chlamydospores and hyphae of Fusarium culmorum by mycoparasitic Pythium species. Plant Pathol. 48:352-359.

8. Don, R. H., Cox, P. T., Wainwright, B. J., Baker, K., and Mattick, J. S. 1991. "Touchdown" PCR to circumvent spurious priming during gene amplification. Nucleic Acids Res. 19:4008.

9. Filion, M., St-Arnaud, M., and Jabaji-Hare, S. H. 2003. Quantification of Fusarium solani f. sp. phaseoli in mycorrhizal bean plants and surrounding mycorrhizosphere soil using real-time polymerase chain reaction and direct isolations on selective media. Phytopathology 93:229235.

10. Godfrey, S. A. C., Monds, R. D., Lash, D. T., and Marshall, J. W. 2003. Identification of Pythium oligandrum using species-specific ITS rDNA PCR oligonucleotides. Mycol. Res. 107:790-796.

11. Hara, H., and Ono, K. 1983. Ecological studies on the bacterial wilt of tobacco, caused by Pseudomonas solanacearum E. F. Smith. I. A selective medium for isolation and detection of Pseudomonas solanacearum. Bull. Okayama Tobacco Exp. Stn. 42:127-138.

12. Hase, S., Shimizu, A., Nakaho, K., Takenaka, S., and Takahashi, H. Pythium oligandrum induces transient ethylene production and reduces the severity of bacterial wilt disease caused by Ralstonia solanacearum in tomato. Plant Pathol. 55:537-543.

13. Kingsnorth, C. S., Kingsnorth , A. J., Lyons, P. A., Chwarszczynska, D. M., and Asher, M. J. C. 2003. Real-time analysis of Polmyxa betae GST expression in infected sugar beet. Mol. Plant Pathol. 4:171-176.

14. Larkin, R. P., and Fravel, D. R. 1999. Mechanisms of action and doesresponse relationships governing biological control of Fusarium wilt to tomato by nonpathogenic Fusarium spp. Phytopathology 89:1152-1161.

15. Lees, A. K., Cullen, D. W., Sullivant, L., and Nicolson, M. J. 2002. Development of conventional and quantitative real-time PCR assays for the detection and identification of Rhizoctonia solani AG-3 in potato and soil. Plant Pathol. 51:293-302.

16. Le Floch, G.., Benhamou, N., Mamaca, E., Salerno, M.-I., Tirilly, Y., and Rey, P. 2005. Characterization of the early events in atypical tomato root colonization by a biocontrol agent, Pythium oligandrum. Plant Physiol. Biochem. 43:1-11.

17. Le Floch, G., Rey, P., Benizri, E., Benhamou, N., and Tirilly, Y. 2003. Impact of auxin-compounds produced by the antagonistic fungus Pythium oligandrum or the minor pathogen Pythium group F on plant growth. Plant Soil 257:459-470.

18. Le Floch, G., Rey, P., Déniel, F., Benhamou, N., Picard, K., and Tirilly, Y. 2003. Enhancement of development and induction of resistance in tomato plants by the antagonist, Pythium oligandrum. Agronomie 23:455-460.

19. Lévesque, C. A., and de Cock, W. A. M. 2004. Molecular phylogeny and taxonomy of the genus Pythium. Mycol. Res. 108:1363-1383.

20. Lewis, K., Whipps, J. M., and Cooke, R. C. 1989. Mechanisms of biological disease control with special reference to the case study of Pythium oligandrum as an antagonist. Pages 191-217 in: Biotechnology of Fungi for Improving Plant Growth. J. M. Whipps and R. D. Lumdsen, eds. Cambridge University Press, Cambridge.
21. Martin, F. N., and Hancock, J. G. 1986. Association of chemical and biological factors in soils suppressive of Pythium ultimum. Phytopathology 76:1221-1231.

22. Martin, F. N., and Hancock, J. G. 1987. The use of Pythium oligandrum for biological control of preemergence damping-off caused by P. ultimum. Phytopathology 77:1013-1020.

23. Martin, F. N., and Kistler, H. C. 1990. Species-specific banding patterns of restriction endonuclease-digested mitochondrial DNA from the genus Pythium. Exp. Mycol. 14:32-46.

24. McQuilken, M. P., Whipps, J. M., and Cooke, R. C. 1990. Control of damping-off in cress and sugar-beet by commercial seed-coating with Pythium oligandrum. Plant Pathol. 39:452-462.

25. Nakaho, K., Inoue, H., Takayama, T., and Miyagawa, H. 2004. Distribution and multiplication of Ralstonia solanacearum in tomato plants with resistance derived from different origins. J. Gen. Plant Pathol. 70:115-119.

26. Newby, D. T., Hadfield, T. L., and Roberto, F. F. 2003. Real-time PCR detection of Brucella abortus: A comparative study of SYBR Green I, 5'exonuclease, and hybridization probe assays. Appl. Environ. Microbiol. 69:4753-4759.

27. Picard, K., Ponchet, M., Blein, J-P., Rey, P., Tirilly, Y., and Benhamou, N. 2000. Oligandrin. A proteinaceous molecule produced by the mycoparasite Pythium oligandrum induces resistance to Phytophthora parasitica infection in tomato plants. Plant Physiol. 124:379-395.

28. Picard, K., Tirilly, Y., and Benhamou, N. 2000. Cytological effects of cellulases in the parasitism of Phytophthora parasitica by Pythium oligandrum. Appl. Environ. Microbiol. 66:4305-4314.

29. Rey, P., Benhamou, N., Wulff, E., and Tirilly, Y. 1998. Interactions between tomato (Lycopersicon esculentum) root tissues and the mycoparasite Pythium oligandrum. Physiol. Mol. Plant Pathol. 53:105-122.

30. Roberts, P. D., Denny, T. P., and Schell, M. A. 1988. Cloning of the egl gene of Pseudomonas solanacearum and analysis of its role in phytopathogenicity. J. Bacteriol. 170:1445-1451.

31. Shibata, D. 2005. Genome sequencing and functional genomics approaches in tomato. J. Gen. Plant Pathol. 71:1-7.

32. Takahashi, H., Ishihara, T., Hase, S., Chiba, A., Nakaho, K., Arie, T., Teraoka, T., Iwata, M., Tsugane, T., Shibata, D., and Takenaka, S. 2006. Beta-cyanoalanine synthase as a molecular marker for induced resistance by fungal glycoprotein elicitor and commercial plant activators. Phytopathology 96:908-916.

33. Takahashi, H., Shimizu, A., Arie, T., Rosmalawati, S., Fukushima, S., Kikuchi, M., Hikichi, Y., Kanda, A., Takahashi, A., Kiba, A., Ohnishi, K., Ichinose, Y., Taguchi, F., Yasuda, C., Kodama, M., Egusa, M., Masuta, C., Sawada, H., Shibata, D., Hori, K., and Watanabe, Y. 2005. Catalog of Micro-Tom tomato responses to common fungal, bacterial and viral pathogens. J. Gen. Plant Pathol. 71:8-22.

34. Takenaka, S., and Kawasaki, S. 1994. Characterization of alanine-rich, hydroxyproline-containing cell wall proteins and their application for identifying Pythium species. Physiol. Mol. Plant Pathol. 45:249-261.

35. Takenaka, S., Nakamura, Y., Kono, T., Sekiguchi, H., Masunaka, A., and Takahashi, H. Novel elicitin-like proteins isolated from cell wall of the biocontrol agent Pythium oligandrum induce defense-related genes in sugar beet. Mol. Plant Pathol. 7:325-339.

36. Takenaka, S., Nishio, Z., and Nakamura, Y. 2003. Induction of defense reactions in sugar beet and wheat by treatment with cell wall protein fractions from the mycoparasite Pythium oligandrum. Phytopathology 93:1228-1232.

37. Thompson, J. D., Gibson, T. J., Plewniak, F., Jeanmougin, F., and Higgins, D. G. 1997. The ClustalX windows interface: flexible strategies for multiple sequence alignment aided by quality analysis tools. Nucleic Acids Res. 25:4876-4882.

38. Van der Plaats-Niterink, A. J. 1981. Monograph of the genus Pythium. Stud. Mycol. 21:1-242.

39. Vasse, J., Frey, P., and Trigalet, A. 1995. Microscopic studies of intercellular infection and protoxylem invasion of tomato roots by Pseudomonas solanacearum. Mol. Plant-Microbe Interact. 8:241-251.

40. Volossiouk, T., Robb, E. J., and Nazar, R. N. 1995. Direct DNA extraction for PCR-mediated assays of soil organisms. Appl. Environ. Microbiol. 61:3972-3976.

41. Wang, P. H., and White, J. G. 1997. Molecular characterization of Pythium species based on RFLP analysis of the internal transcribed spacer region of ribosomal DNA. Physiol. Mol. Plant Pathol. 51:129-143.

42. Weiland, J. J. 2003. Transformation of Pythium aphanidermatum to geneticin resistance. Curr. Genet. 42:344-352.

43. Whipps, J. M. 2001. Microbial interactions and biocontrol in the rhizosphere. J. Exp. Bot. 52:487-511. 